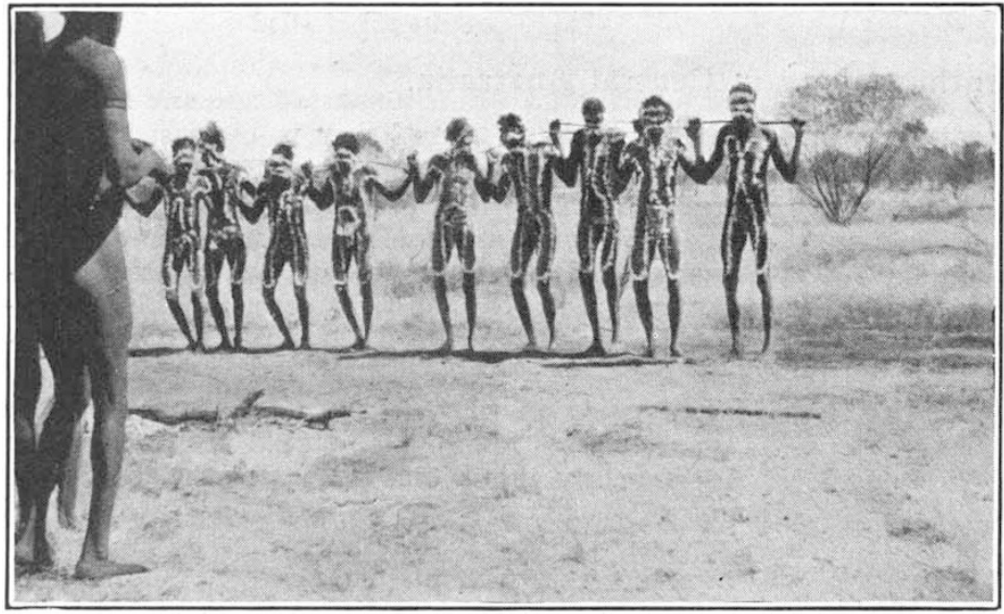

FIr. 3,-Performers in the tjilpa, a native cat ceremony.

natives, and also of scarred chests, of hands and feet, and of special anatomical features.

A considerable quantity of general ethnological data and photographs was secured on native customs, ceremonies, arts and crafts, as well as a valuable collection of native objects.

A vocabulary of approximately three hundred words was taken down, and native songs were recorded on phonograph cylinders. Cinematograph records were taken on both standard width and $\mathbf{1 6}$ $\mathrm{mm}$. films, a certain amount of the latter being on natural colour film.

Although the natives were entirely uncivilised, no difficulty was experienced in obtaining their complete confidence and

scientific programme and the extent of the work carried out :

Genealogical data were recorded on ninety individuals. On fifty natives, routine anthropometric and descriptive anatomical observations were made. Standard photographs were taken of each individual.

The hair tracts of twenty - four children were charted. Other physical data such as skin creases, dermatoglyphs, spinal curves, and foot outlines, were secured on approximately forty individuals.

Blood grouping, entailing, with cross testing, about a thousand observations, was made on ninety natives. These results showed that sixty-four belonged to group A and twenty-six to group 0 .

The basal metabolism was estimated on forty-two individuals, and these, with associated tests on blood pressure, pulse, and respiration rates, etc., have produced some extremely interesting data.

On groups of individuals, varying from twenty-five to fifty in number, tests were carried out on the special senses, such as visual and auditory acuity; pain tests, strength tests, and special perception and intelligence tests were also made.

Excellent plaster casts were obtained of the faces of seventeen

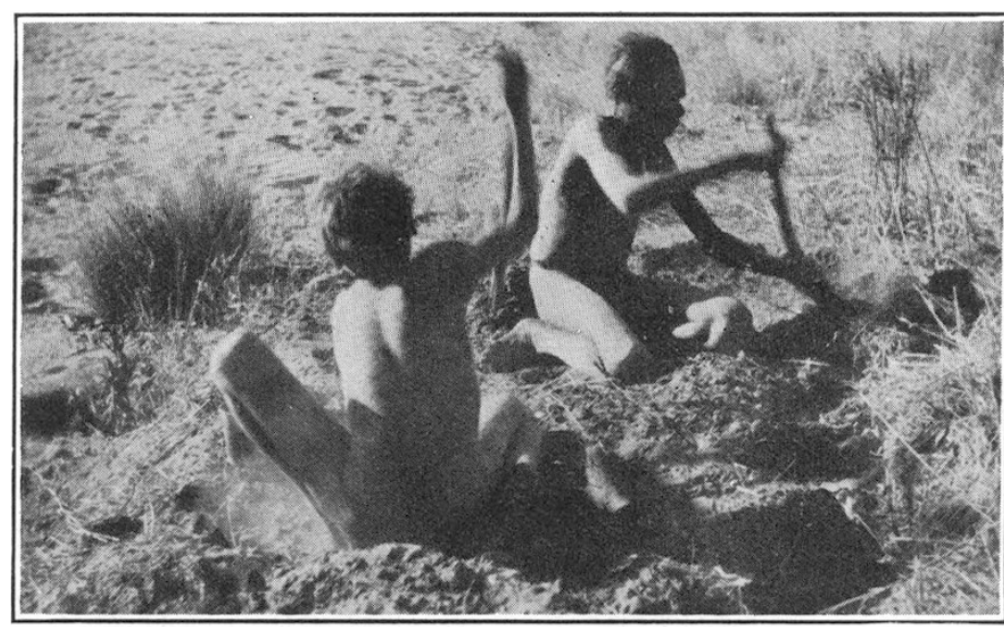

FIG. 4.-Digging yelka (Cyperus rotundus) from the creek bank.

\title{
Genesis of Ores in Relation to Petrographic Processes.
}

$\mathrm{T}$ HE development of theories of ore genesis since their discussion at the British Association meeting in 1833 was briefly referred to in his presidential address to Section C (Geology) by Prof. J. W. Gregory. He remarked that the belief in the deep-seated origin of ores had been at one time superseded by their assignment to lateral secretion and later to the igneous rocks. He assigned the source of the lode metals to a deepco-operation, a very interesting factor when it is considered that a number of the procedures, such as the routine of basal metabolism, the taking of plaster casts of the face, and the drawing of blood for blood grouping, might easily be expected to cause fear, resentment, or suspicion.

This expedition has been probably the most successful and fruitful venture that has yet been carried out in investigating the biological aspects of Australian aboriginal anthropology. The detailed results of the work will be published in due course.

$$
\text { No. 3247, VoL. 129] }
$$

seated zone below the level of the ordinary igneous rocks, and regarded the occasional occurrences of lode metals in them as secondary. The trend of the discussion in the Geological Section on Sept. 29 supported these views.

The conference had the advantage of being opened by Prof. G. C. Cullis, who gave a luminous exposition of the formation of ore deposits by the segregation of the more valuable metals into local 
concentrations. The processes may be classified, as with rocks, into the sedimentary, of which the ore products except of iron, are relatively insignificant; the metamorphic, which are comparatively unimportant; and the igneous, which exceed the others in economic value. Prof. Cullis regards the segregation of the ores in igneous rocks as an extreme development of magmatic differentiation, and he explained the process as in most cases due to hydrothermal solutions forming mineral veins. He remarked in conclusion that although there is now a general approximation as to ore formation in the petrogenic scheme, agreement has not been reached as to the actual process of mineralisation in any one of the main metalliferous fields. This paper is being published in the Report of the Association.

Prof. P. Niggli, of Zurich, dealt mainly with metamorphic ores, as so large a measure of agreement has been reached regarding the two other groups. The magmatic ores he classified into three sections : the orthomagmatic, those formed during the main consolidation of the igneous rock; the pegmatitic-pneumatolytic, those due to volatile constituents at high temperatures ; and the hydrothermal, those deposited by aqueous solutions, exhalations, thermal waters, etc. The second main group or sedimentary ores are concentrations of matter derived by the weathering of rocks, whether deposited mechanically or by solution. They are sometimes influenced by epi-metamorphism, as with the gold deposits of the Witwatersrand, which in his opinion are undoubtedly sedimentary placer deposits. He described the metamorphic oredeposits as often characterised by a profusion of rare minerals, such as the two hundred species at the Langban mine in Sweden, more than a hundred species at the Franklin Furnace mine, New Jersey, and the varied sulpho-salts of Langenbeck in the Binnental. Remarkable mine structures are due to dislocation metamorphism, as at Rammelsberg in the Harz, and he suggests as possible examples the pyritic masses of Rio Tinto and similar deposits. The character of these ores is often due to their mechanical deformation and recrystallisation during rock metamorphism. The poverty of ores in the central Alps is due to the magmatic solutions being barred in their ascent. He urged in conclusion that the study of ore genesis is the starting-point for the estimation of the world's reserve of minerals and for the framing of future economic policy.

Prof. Percy Quensel, of Stockholm, also dealt with metamorphic ores and illustrated the need in their interpretation of dealing with the changes in the enclosing rocks by reference to the iron ores of central Sweden. His conclusions are similar to those advocated in a review in Nature, Aug. 29, 1931, p. 384, of two recent Swedish monographs on these ores. These iron ores occur in the leptite formation, which consists mainly of altered acid lavas and tuffs that have been altered into granulitic gneisses. The bedded siliceous and calcareous ores in the lower part of the formation are altered sediments. The skarn ores are due to four stages : (1) metasomatic mineralisation of limestone and dolomite; (2) formation of the 'reaction-skarn' by thermo-metamorphism with production of simple ore minerals, and local enrichments along the axes of folds ; (3) intense faulting and crushing with metasomatic formation of magnesian minerals, producing 'skol' or crush-rock, and the development of albite or quartzite in the adjacent leptite ; (4) local contact alteration and renewed development of skarn-minerals by the intrusion of the younger pre-Palæozoic granites.

Such ores are therefore due more to metasomatic processes than to magmatic segregations. Dr. A. Brammall threw doubt on the primary nature of the lode metals found in granite as the results of a searching investigation of the Dartmoor granite. It contains rare gold which has been regarded, as in other cases, as a primary constituent. Dr. Brammall proved by an elaborate series of analyses and petrographic study that the Dartmoor granite has absorbed so much of the rocks into which it was intruded that the lode metals found in it may be regarded as derived from the assimilated sediments. He also threw doubt on the current theories of rock differentiation.

The lead-zinc veins of the north-eastern Pennines played a conspicuous part in the discussion on mineral veins in 1833. Current opinion on these ores was explained by Mr. K. C. Dunham, who contrasted the alternative theories-the formation of the lodes by meteoric waters dissolving ore particles from the country rocks, and their deposition by ascending deep-seated solutions. He showed that the evidence of the vertical zonal distribution of the ore, now established through the field as a whole, of the abundant fluor-spar which indicates the derivation of the ore-bearing solution from an acid magma, and of the various rare elements, all support a deep-seated origin. The surface waters, moreover, deposit only such minerals as calcite, limonite, and oxides even in the presence of abundant pyrite. The richness of the ore in the upper parts of the veins is due to the interaction there between the deep-seated and ground waters.

Mr. G. Vibert Douglas summarised the modes of origin of the chief mines of Northern Rhodesia. The Katanga type of copper and cobalt ores in dolomite he explained by an experiment he had made at N'Changa in which a solution of copper carbonate, after filtering for ten days through powdered dolomite, lost its copper ; the dolomite was stained green by malachite. $\mathrm{He}$ attributes this type of ore, therefore, to the introduction of sulphide solutions and their concentration and deposition as carbonates. The ores of the Roan Antelope and N'Kana he attributes to the infiltra. tion of primary sulphides, and their concentration near intrusive granite and pegmatite, and in places by deposition far from any igneous rock. The Broken Hill zinc-lead ore-bodies are pipe-like masses in dolomite. The iron-manganese ores are akin to bog iron and manganese beds, and the metals were derived from a shale that had been intruded by granite.

Dr. G. W. Tyrrell contended that it is not possible to deny the term 'magmatic' to ore deposits which 
are due to the action of late magmatic residues in which water is always the predominating constituent. These deposits have been termed ' hydrothermal' by Niggli, but this usage does not distinguish between deposits of truly magmatic origin and those due to heated waters of non-magmatic derivation. There seems to be need for a term to cover the latter, although admittedly there is often difficulty in distinguishing between the two types. Perhaps the best solution would be to use the term hydrothermal for all cases of ore deposition by heated waters, and to prefix the term "magmatic" for those in which the magmatic origin of most or all of the water is demonstrable.

Dr. Tyrrell also dealt with ore deposition and the distribution of igneous rocks, and contended that ore provinces follow the distribution of igneous provinces as between the kratogenic and orogenic regions of the crust in any given period of tectonic and igneous activity.

The complexity of origin of ores was emphasised by Prof. R. W. Brock, of Vancouver, and he welcomed Prof. Niggli's sharp distinction between ores due to the solidification of the main mass of a magma, the products of the semi-liquid extract, and the products of the fluid extract that remain in solution through a long range of temperatures. The diversity of opinions upon particular ore deposits, remarked by Prof. Cullis, he considered satisfactory, as it shows that each deposit is being treated individually, as is necessary since more than one process is involved in most cases. Thus the Kiruna iron ores he regards as due in part to ortho-magmatic differentiation from the local syenite-porphyry, in part to later pegmatitic injection, and in part also to vein formation. He was glad that the Kiruna ore may still be considered as in part orthomagmatic, as unquestionable examples of this mode of formation are now difficult to locate. As Prof. Cullis mentioned, the nickel-ores of Sudbury are not altogether safe examples, for Dr. Cyril Knight has assembled a large number of observations that cast great doubt on their orthomagmatic origin, and Dr. T. C. Phemister has brought to light a disquieting amount of evidence that the Sudbury sill consists not of one rock show. ing pronounced gravity differentiation, but of two distinct rocks. Prof. Brock remarked that we can ill afford to lose this classical illustration of this possible type of ore formation, but it may be wise to prepare ourselves for such a calamity. He considers that small ore deposits are often the more instructive as to processes of formation, and that the problems of economic geology must be solved by patient and informed study in the field, laboratory work being accessory and supplementary.

\section{Obituary.}

\section{Dr. S. E. Lane-Poole.}

W $\mathrm{E}$ regret to record the death of Dr. Stanley Lane-Poole, the distinguished orientalist, which took place at his residence in Brompton Square, London, on Dec. 29, at the age of seventyseven years. Dr. Lane-Poole, who was born in London on Dec. 18, 1854, was the son of Edward Stanley Poole, of the Science and Art Department, and a great-nephew of $\mathrm{E}$. W. Lane, the translator of the "Arabian Nights", the author of "The Modern Egyptians", and the compiler of an Arabic lexicon-a connexion in which he took considerable pride and emphasised by incorporating "Lane" by a hyphen in his surname.

After being educated privately, Lane-Poole entered Corpus Christi College, Oxford, in 1874, with the declared intention of devoting himself to Oriental studies. Before he took his degree in 1877, when he obtained a third class in the honours school of modern history, he was already at work in the Coin Department of the British Museum, and in 1875 had begun the publication of the Museum catalogue of Oriental and Indian coins, which was completed in fourteen volumes in 1892. He was sent by the Government on archæological missions to Egypt in 1883 and to Russia in 1886, and from 1895 until 1897 was employed in archæological research in Cairo. From 1898 until 1904 he was professor of Arabic at Trinity College, Dublin, acting for part of that period as secretary to the Council of the Royal Irish Academy.

The remainder of Lane-Poole's life was devoted to literary work and research. He was the author of a number of works, some of a highly specialised character, some of a wider appeal, and of several biographies of notabilities, such as Lord Stratford de Redcliffe, Ambassador to Constantinople; Sir Harry Parkes, Minister to China and Japan; and others whose activities had been in fields in which he was interested. Two of his works of outstanding importance in Oriental studies were "Muhammedan Dynasties" (1893), a standard work of chronological reference for scholars, and the Arabic lexicon which he edited from the material amassed by Lane and published in 1893 after a labour of sixteen years. Of a large number of scholarly works dealing with the culture, art, and history of the Moslem world, the best known are "The Art of the Saracens in Egypt" (1886) and the volume on medieval India in the "Story of the Nations" series, which reached its ninth edition.

\section{Prof. A. W. Kirkaldy.}

Prof. A. W. KIRKaLdy, until recently professor of economics and commerce at University College, Nottingham, and, prior to 1919 , professor of finance in the University of Birmingham, who died on Dec. 29, 1931, aged sixty-four years, was one of the few British economists of the generation of teachers, now passing away, who had actual experience of routine business management for he did not enter Wadham College, Oxford, to take up academic studies until he had served in a family business in Sunderland, in many capacities, for several years. It was only natural, therefore, that 